TECHNICAL COMMUNICATIONS AT.SASKATCHEWAN TECHNICAL INSTITUTE,

\section{MOOSE JAW}

George Louks

Technology programs at the Saskatchewan Technical Institute aie unte and one-half to two-year diploma courses. The Institute is coeducational and most students are high school graduates (Grade $\mathrm{x} / 1$ ) from urban and rural areas.

The Communications Department at S.T.I. is centralized In that it is part of the Related Subjects Division of the school, and it services the other departments (courses). Related subjects includes three sections: Communications, Mathematics and Physics and Chemistry, with the Communlcatlons Department further divided into Business and Technical Communications. A centralized department means that the Communications Instructor serves two masters, his own department head and the head of the department or technology he works with. This could easily lead to problems, but we have found that mutual goals and co-operation have made the system work smoothly and successfully.

\section{TECHNOLOGY AND COMMUNICATIONS COURSES}

The following table lists the S.T.I. technology courses, their length, and the time allotted to communications:

\begin{tabular}{lll} 
TECHNOLOGY & $\begin{array}{l}\text { COURSE } \\
\text { LENGTH }\end{array}$ & $\begin{array}{l}\text { TIME ALLOTTED TO } \\
\text { COMMUNICATIONS }\end{array}$ \\
\hline Architectural Engineering & 2 Years & $\begin{array}{l}3 \text { hours per week in the } \\
\text { Ist year }\end{array}$ \\
\hline Civil Englneering & 2 Years & $\begin{array}{l}2 \text { hours per week in the } \\
2 n d \text { year }\end{array}$ \\
\hline Electrical Engineering & 2 Years & $\begin{array}{l}2 \text { hours per week in the } \\
\text { 2nd year }\end{array}$ \\
\hline Electronics Engineering & 2 Years & $\begin{array}{l}2 \text { hours per week in the } \\
\text { 2nd year }\end{array}$ \\
\hline
\end{tabular}

\begin{tabular}{lll}
\hline $\begin{array}{l}\text { Engineering Drafting } \\
\text { and Surveying }\end{array}$ & 2 Years & $\begin{array}{l}3 \text { hours per week in the } \\
\text { Ist year only }\end{array}$ \\
\hline Industrial Instrumentation & $\begin{array}{l}\text { Y and } 1 / 2 \\
\text { Years }\end{array}$ & $\begin{array}{l}3 \text { hours per week in the } \\
\text { Ist year only }\end{array}$ \\
\hline Radiation Protection & I Year & 3 hours per week \\
\hline
\end{tabular}

NOTE: * Future courses may include a third semester of communications.

A typical two-year technology course might be broken down into four semesters thus:

\section{First Semester}

Covers the general principles of oral and written communications including reading comprehension, a brlef review of English Gramar, and an introduction to technical writing. At least two prepared speeches are given in the oral portion.

Second Semester

In this semester, the principles of communications, covered in the first semester, are applied in different business and technical situatlons and include a greater emphasis on technical writing. At least two prepared speeches are given with the use of visual aids being introduced.

\section{Third Semester}

Continues with technical writing to cover informal and formal reports. The work involves the organization and interpretation of data and its presentation in sultable format together with supporting graphlcs and documentation. Oral work related to the student's partlcular technology will be included.

\section{Fourth Semester}

Requires the student to apply his previous learning to the wrlting of semi-formal and formal reports of approximately 2500 words in length and related to his technology. The student should draw on his 
studies, work experience, laboratory exercises and research in related literature. The student presents an oral report of his written report. Some introductory specification and proposal writing will be included in the course.

A separate Oral Communications course is given to only the Engineering Drafting and Surveylng students in their first year lone hour per week). The course concentrates on the study and practice of effective speaking techniques. Emphasis is placed on the building of confidence through the presentation of prepared talks. Other areas covered are communicatlons principles, outlining, critical thinking, speech evaluation, and the use of audio-visual aids.

\section{DEVELOPMENT OF TECHNICAL COMMUNICATIONS AT S.T.1.}

The present Technical Communications course at S.T.1. evolved slowly from offerlngs of "Composition and Literature" to a fairly compre-

hensive course which is adapted to the specific needs of the technology in whlch it is used.

The school opened in 1959 with grammar and literature taught in the first year followed by a potpourri of films and discussions in the second year. The next year, a course in report writing was designed around the format and style used by Imperial 011 , to be taught, in the second year. The two-year course now consisted of grammar and literature in the first year, followed by Report Writing in the second.

General Semantics was introduced into the second semester in 1964, and the course remained thus until 1971 when it began to resemble its present form. Technlcal Writing took the place of General Semantics, which seemed a more practical approach to teaching Report Writing in the second year. The course was patterned to a great extent after the content of Wrlting and Reading in Technical English (1969) by Pickett and Laster since this was the text adopted for use in the revamped course. Oral communications was introduced at this stage to prepare the student for his oral report in the final semester of his course.

The course was brought further up to date in 1979, when the first and second years were merged into Technical Communications, and the formal report became an end product rather than having a full year devoted to $i t$.

As the course stands today, the two years of Technical Communications merge from one year to the next rather than being two separate entities. Some of the subjects covered (not necessarily in this order) are: Reading and Comprehension, Summary Writing, Instructions, Explanation of a Process, Description, Business Correspondence (including the Application Letter and Resume), Proposals, Speciflcations, Research Methods, Analysis, Visual Aids, and Report Writing.

Over the past ten years, a variety of texts have been used as new approaches and up-dating of materlal were required. We are currently using Occupational English by Laster and Pickett, and Technical Writing by Lannon. Instead of an English handbook, we have found English Simplified by Ellsworth to be easler for the student (and instructor) to use as a quick and practical reference.

\section{A WORD ABOUT ORAL COMMUNICATIONS}

Oral Communications has become an increasingly important part of the Technical Communications course because of both its immedlate and future value to the student. The preparation and dellivery of speeches not only teaches the student how to outline and organize material, but also instills confidence in him and makes him an asset to any future employer. The graduate student who is able to express himself with clarlty and confidence to a customer or group makes an excellent representative for any business. Because we belleve this, we have devoted considerable time to this portion of the course. We have also found that self-evaluation has more impact than a critique by someone else; therefore, we use VTR (Video Tape Recording) for the student to see and hear himself as his audience does.

\section{A SALES PITCH FOR CATTW}

Last June, I had the opportunity to attend TWIT (the Technical Writing Institute for Teachers) held at the Rensselaer Polytechnic Institute in Troy, New York. It was like a breath of fresh alr in a 
desert. I was pleased to find that what we offered S.T.I. students was generally the same as other courses available at institutes across Canada and the United States. With my introduction to ATTW (The Assoclation of Teachers of Technical Writing), I found we were no longer alone and in the dark but had the reassurance of experts that we were on the right track. I am sure that in the coming years the CATTW wIll be a great help to Canadian teachers who are planning, revising, or teaching Technical Writing and Technical Communications.

Let's have a Canadian conference of teachers of technical writing soon!

\section{AUTOBIOGRAPHICAL NOTE BY THE AUTHOR}

I was born In Essex, Ontarlo, and mis-spent most of my youth in Windsor, Ontario, which is just south of the United States. (If you don't believe me look it up on a map!) After graduation from high school in 1943, I jolned the RCAF and spent most of the next two years earning my pllot's wings: "Never in the field of human conflict have so many been confused by so few." After release from the RCAF in 1945, I spent a few years at the Unlversity of Western Ontario (London) and Assumption College (Windsor) accumulating credits for my B.A. A further year at OCE (Ontario College of Education, Toronto) earned me a High School Teacher's Certificate In 1951. While

attending OCE, I rejoined the RCAF with a permanent commission as a pllot. Durlng the years from 1951 to 1969, I instructed fledgling pllots, both on the ground and in the air, (hours and hours of utter boredom interspersed with moments of sheer terror!)

Four glorlous years were spent in Europe with 423 All Weather Fighter Squadron flying the CF-100, the only all-Canadian fighter ever produced. During my air force career, I accumulated a wife and three beautiful daughters; the two youngest were born in France, and the last one I delivered myself in the front seat of our car in the middle of a small French village. (Nelther my daughter nor I have recovered from the shock to this day!)

We moved to Moose Jaw in 1965, when I was transferred to \#2 Flying
Training School as an instructor. When I retired in 1969, I promptly joined the staff at the Saskatchewan Technical Institute where I sit even now. 


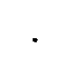

.

. 